\title{
Fast establishment and application of caspase-3 inhibitor detection
}

\section{system}

\author{
Dan $\mathrm{Wu}^{1, \mathrm{a}}$, Hongye Zhao ${ }^{1, \mathrm{~b}}$, Huan $\mathrm{Liu}^{1, \mathrm{c}}$, Peng $\mathrm{Yu}^{1, \mathrm{e}}$, and Yuou Teng ${ }^{1, \mathrm{f}^{*}}$
}

${ }^{1}$ Key Lab of Industrial Fermentation Microbiology,Tianjin Key Lab of Industrial Microbiology, Tianjin University of Science and Technology, Tianjin, P. R. China

a wudan2013126@126.com, , zhaohongye610@126.com, cliuhuan1486@163.com, ${ }^{d}$ tyo201485@tust.edu.cn, e yupeng@tust.edu.cn ,

Keywords: Recombinant human Caspase-3 . Expression . Purification. Ac-DEVE-CHO.

Abstract:Our objective to study the expression and activity of the apoptosis protease Caspase-3 in E. coli BL21 (DE3) Plyss. The cDNA of Caspase-3 was amplified by PCR and inserted into the cell of K562, it was then cloned to prokaryotic expression vector pET-21b, after which Caspase-3 was induced by IPTG. The Protein induced was identified by SDS-PAGE and Western blot. After induced by IPTG for 5 hours, the concentration of Caspase-3 reached the highest level. Finally active Caspase-3 can be induced within E. coli BL21 (DE3) Plyss, further research can be done to chose the Caspase-3 inhibitors.

\section{Introduction}

Caspases play important roles in apoptosis and cell signaling. Caspase- 3 is the core of the execution phase of apoptosis [1] . Caspase-3 has become attractive target in the treatment of many disease such as Alzheimer [2], Parkinson's [3], myocardial infarction [4] and cancer [5]. Thus, key apoptosis factors serve as attractive molecular targets for designing specific pharmaceuticals for apoptosis diseases [6]. So Caspase-3 is identified as a drug-screening target. Caspase inhibitors have anti-cancer and other pharmalogical potentials. It has been proven that Caspase-3 substrate selectivity for the peptide sequence Asp-Glu-Val-Asp (DEVD) [7]. Our strategy was to establish Caspase-3 inhibitor rapid screening platform and Ac-DEVE-CHO [8-10] can be used as a control.

\section{Materials and methods}

\section{Plasmid construction.}

Human Caspase-3 full-length cDNA was amplified by the cell of K562. cDNA was used as a template for PCR amplification of the region in the open reading frame encoding the mature human Caspase-3. PCR amplification was performed using $25 \mathrm{ng}$ of template DNA, $0.1 \mathrm{ng}$ of the appropriate primers [5'- GCGAATTCATGGAGAACACTGAAAAC -3' (5'-primer) and 5'GCGCGGCCGCTTAGTGATAAAAATAGAG-3'(3'-primer)], and $1 \mathrm{U}$ of Pfu turbo DNA polymerase (Stratagene) in a final reaction volume of $20 \mu \mathrm{L}$. The reaction mixture was subjected to amplification for 35 cycles ( $94 \mathrm{C}, 0.5 \mathrm{~min} ; 55 \mathrm{C}, 0.5 \mathrm{~min} ; 72 \mathrm{C}, 1.5 \mathrm{~min}$ ) using a thermal cycler. The result of Caspase-3 PCR is shown in Fig.1. After purification, PCR products were cleaved with EcoRI and NotI and ligated between the corresponding restriction sites of the vector pET-21b.This vector has a His-tag coding sequence and can produce a C-terminal 6 His-tag fusion protein. The 


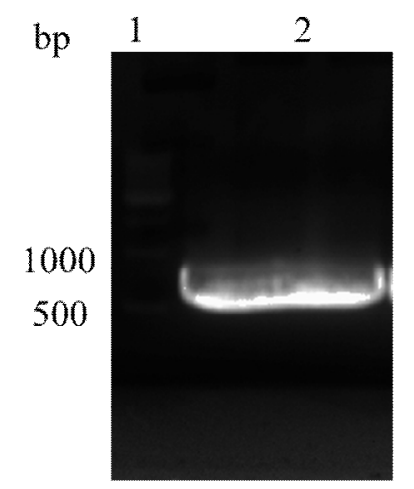

Fig. 1

Fig.1: lane 1:Maeker

lane 2:caspase-3

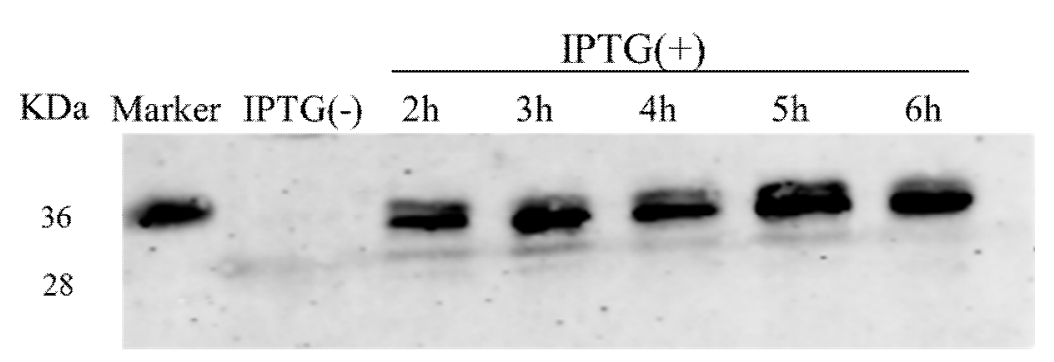

Fig.2

Fig.2: $1 \mathrm{mM}$ IPTG induced the expression of Caspase-3 increased with increasing time and the maximum expression at $5 \mathrm{~h}$.

double digestion products of fragment Caspase-3 and vector connection at $16{ }^{\circ} \mathrm{C}$ overnight . Then the ligation product was transformed into competent in E.col top 10 Screening of positive transformants were used to induce the expression of Caspase- 3 protein and then to study the function and activity of other aspects.

\section{Expression of the recombinant human Caspase-3}

To express the recombinant human Caspase-3, E. coli BL21(DE3) Plyss cells were grown in LB medium ( $1 \%$ bactotryptone, $0.5 \%$ yeast extract, $0.5 \% \mathrm{NaCl}$ ) containing $100 \mu \mathrm{g} / \mathrm{mL}$ ampicillin at $37{ }^{\circ} \mathrm{C}$ to OD600 $\mathrm{nm}=0.6-0.8$.Isopropyl $\beta$-D-1-thiogalactopyranoside (IPTG) was then added to a final concentration of $1 \mathrm{mM}$ and cells were further incubated for $1 \mathrm{~h}-5 \mathrm{~h}$ at $16{ }^{\circ} \mathrm{C}$. The result of SDS-PAGE analysis was used to determine the optimal conditions for the expression of Caspase-3.

\section{Purification of caspase-3.}

Single colonies were used to inoculate a $5 \mathrm{ml}$ LB medium, containing the appropriate antibiotic and were then grown at $37{ }^{\circ} \mathrm{C}$ overnight. This culture was used to inoculate $50 \mathrm{ml}$ of LB medium (added in $50 \mu \mathrm{L}$ Ampicillin) at $37{ }^{\circ} \mathrm{C}$ to $\mathrm{OD} 600 \mathrm{~nm}=0.6$. Isopropyl $\beta$-D-1-thiogalactopyranoside (IPTG) was then added to a final concentration of $1 \mathrm{mM}$ and cells were further incubated for $5 \mathrm{~h}$ at $16^{\circ} \mathrm{C}$. The inclusion bodies of Caspase- 3 were prepared by cell lysis in a buffer containing $20 \mathrm{mM}$ Tris- $\mathrm{HCl}(\mathrm{pH} 8.0), 500 \mathrm{mM} \mathrm{NaCl}$. Cells were broken using an noise isolating tamber (Ningbo Scienfz Biotechnology Co, LTD). The protein were supernatant by centrifugation at $5000 \times \mathrm{g}$ for 5 min at $4{ }^{\circ} \mathrm{C}$ and loaded on a Ni2+-nitrilotriacetic acid at $4{ }^{\circ} \mathrm{C}$ over night. The Caspase- 3 was eluted using a buffer containing $20 \mathrm{mM}$ Tris- $\mathrm{HCl}(\mathrm{pH} 8.0), 500 \mathrm{mM} \mathrm{NaCl}, 150 \mathrm{mM}$ imidazole. Fractions containing the Caspase-3 proteins were concentrated by Dialysis at $4{ }^{\circ} \mathrm{C}$ overnight $\left(\mathrm{Na}_{2} \mathrm{HPO}_{4} \cdot 12 \mathrm{H}_{2} \mathrm{O} 16.692 \mathrm{~g}, \mathrm{Na}_{2} \mathrm{H}_{2} \mathrm{PO}_{4} \cdot 2 \mathrm{H}_{2} \mathrm{O} 0.53 \mathrm{~g}, \mathrm{NaCl} 5.844 \mathrm{~g}\right.$, Glycerin100ml and water $\left.900 \mathrm{ml}\right)$. And then Caspase- 3 were supernatant by centrifugation at $5000 \times \mathrm{g}$ for $5 \mathrm{~min}$ at $4{ }^{\circ} \mathrm{C}$.

\section{caspase- 3 activity assay}

For determination of inhibitor potency against the purified enzyme, inhibitors were titrated against recombinant Caspase- 3 and the enzyme activity was measured by Caspase- 3 activity assay kits (Tianjin Sungene Biotech Co.,Ltd) .The Amplite ${ }^{\mathrm{TM}}$ Fluorimetric Caspase-3 Assay Kit uses Ac-DEVD-AMC as a fluorogenic indicator for Caspase-3 activity. AMC peptides are almost non-fluorescent. Cleavage of AMC peptides by Caspase- 3 generates strongly fluorescent AMC that is fluorimetrically monitored at $450 \mathrm{~nm}$ with excitation of $350 \mathrm{~nm}$. It can be used to continuously measure the activities of Caspase- 3 in cell extracts and purified enzyme preparations with a fluorescence microplate reader or fluorometer. The Caspase-3 activity assay kits containing Component A: the fluorogenic tetrapeptide substrate Ac-DEVD-AMC (10 mM), Component B:Assay buffer: (20 mM Hepes buffer with 4 mM EDTA),C:1M DTT. The Caspase-3 activity 
assay using a 384-well (Corning 3573). Each well contained $15 \mu \mathrm{L}$ working solution (the component A 、 B and C (v/v/v) (2:100:1) 、 $15 \mu \mathrm{L}$ enzyme 、0.5 $\mu \mathrm{L}$ Compound). After incubated, the solution was determined immediately (excitation at $350 \mathrm{~nm}$, emission at $450 \mathrm{~nm}$ ).

\section{Results and discussion}

\section{Expression and purification Caspase-3}

The optimum conditions of the expression human caspase- 3 is : $1 \mathrm{mM}$ IPTG induced $5 \mathrm{~h}$ at $16^{\circ} \mathrm{C}$.After IPTG induction, Caspase-3 was expressed as a major protein at $31 \mathrm{kDa}$ in the total protein of E. coli, as shown in Fig. 2. The size of expressed Caspase-3 was in good agreement with the theoretical molecular weight from the amino acid sequence of the lec-EGF domains and 6 His-tag. The protein was expressed mainly as soluble protein. After sonication Caspase-3 protein sample was purified by single step $\mathrm{Ni}^{2+}$ affinity chromatography with the purification tags. The result of SDS-PAGE analysis for the purification of Caspase-3 is shown in Fig. 3. The molecular weight of the soluble protein was evaluated as about $31 \mathrm{kDa}$.

Fig.3:lane 1:OD600 $\mathrm{nm}=0.6$

lane 2:IPTG induction $5 \mathrm{~h}$

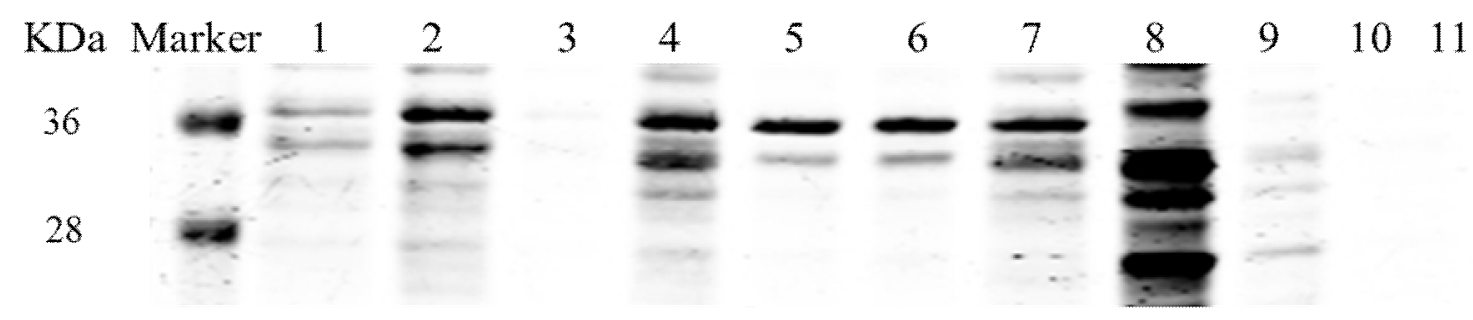

Fig. 3

lane 3 :centrifugal cell supernatant

lane 4:After cell sonication

lane 5:supernatant after sonication

lane 6: After sonication precipitate

lane 7:the supernatant after centrifugation combined beads

lane 8:first elution

lane 9:second elution

lane 10:the third elution

lane 11:beads after elution

\section{Caspase-3 inhibition assay.}

To determine the in vitro inhibitory potencies of Ac-DEVE-CHO toward Caspase-3, the recombinant enzyme was preincubated on ice in $20 \mathrm{mM}$ HEPES, $0.1 \mathrm{M} \mathrm{NaCl}, 10 \%$ sucrose, $0.1 \%$ CHAPS and $2 \mathrm{mM}$ EDTA(pH 7.4) and the final concentration of the Caspase- 3 is $5 \mathrm{ng} / \mathrm{ml}$. The increasing concentrations of Ac-DEVE-CHO's final concentration is $0.1 \mathrm{nM}, 0.3 \mathrm{nM}, 1 \mathrm{nM}, 3 \mathrm{nM}, 10$ $\mathrm{Nm}, 30 \mathrm{nM}$ wereadded. The percentage of cleavage was evaluated and compared with $100 \%$ relative activity, and the IC50 value was determined accordingly. By calculating the IC50 value of the Ac-DEVE-CHO is $2.28 \pm 0.05$.

\section{Conclusion}

In this study, simplified and efficient Caspase-3 assay was established. Our work has shown that the Ac-DEVE-CHO has strong Caspase-3 inhibitory activity. In the next study, Ac-DEVE-CHO can be used as a Caspase-3 inhibitor screening test control. This study may provide valuable information for development of inhibiting apoptosis with more potent activities. 


\section{Acknowledgment}

The authors sincerely thank the financial support from National Natural Science Foundation of China (31301142).

\section{References}

[1] Hacker H.G, Siasy M.T. Synthesis, Allosteric modulation of caspases Pharmacol, Gutschow M.132 (2011) 180-195.

[2] Alteri D.C, Survivin and IPA proteins in cell-death mechaisims,Biochem.J.430(2010) 199-05.

[3] Gusella J.F, Mac Donald M.E,Unmasking polyglot amine triggers in neurodegenerative disease. Natue Rev NeurosciJ.1 (2000).

[4] Aziz G, Alselsen Ø.W, Hansen T.V, Paulsen R.E, Procaspase-activating compound 1 induce a caspase-3 dependent cell death in cerebellar granule neurns. Appl.Pharmacol.247 (2010) 238-242.

[5] Hanahan D, Weinberg R.A,Hallmarks of cancer:the next generation.Cell. 144 (2011) 646-674.

[6] Saka,J,Yoshimori A,Nose Y,Mizoroki A,Okita N,Takasawa R,Tanuma S, Bioorg.Med.Chem. 16 (2008) 4584.

[7] Imre G, Heering J, Takeda AN, Husmann M, Zu Heringdorf DM, Green DR, Van der Goot FG,Sinha B, Dotsch V,Rajalingam K.Caspase-2 is an initiator caspase responsible for poe-forming toxi-mediated apoptosis. EMBO J. (2012).

[8] Crawford E.D, Wells J.A, caspase substrates and cellular remodeling,Annu.Rev.Biochem. 80 (2011) 1055-1087.

[9] Fasulo L,U golini G,Visntin M, The neuronal microtubule-associate protein tau is a substrate for caspase-3 and an effector of aoptosis , J N eurochem. 75.2(2000) 624-633.

[10] Crawford E.D,Wells J.A, Caspase substrates and cellular remodeling,Annu.Rev.Biochem. 80 (2011) 1055-1087. 